\title{
The coalition and constitutional reform
}

\author{
by Vernon Bogdanor
}

$\mathrm{B}$ ritain is currently experiencing her first peacetime coalition government since the 1930s, a coalition which arose out of her first hung Parliament since 1974. It was an unexpected outcome. Previously coalitions have arisen not from hung Parliaments, but from national emergencies - war in 1915, 1916 and 1940, financial emergency in 1931. In the past, hung Parliaments, as in 1923, 1929 and 1974, have led to short-lived minority governments, not coalitions.

Not only is the formation of a peacetime coalition following a hung Parliament a constitutional innovation, but the coalition promised a whole raft of constitutional reforms, the most important of which are fixed-term Parliaments and a directly elected second chamber, together with the referendum on the alternative vote method of election, held in May 2011. Indeed, the Deputy Prime Minister, Nick Clegg, declared in a speech shortly after the formation of the coalition, on 19 May 2010, that its constitutional reforms amounted to:

"the most significant programme of empowerment by a British government since the great enfranchisement of the 19th

century... The biggest shake-up of our democracy since 1832, when the Great Reform Act redrew the boundaries of British democracy, for the first time extending the franchise beyond the landed classes."

It is already apparent that the era of constitutional reform, which began with the Blair government in 1997, and which I tried to chart in my book, The New British Constitution, published in 2009, is not yet complete. Reform of the constitution is most definitely a process, not an event.

The Coalition Agreement, published on the formation of the government, declared:

\footnotetext{
"Our political system is broken. We urgently need fundamental political reform, including a referendum on electoral reform, much greater co-operation across party lines, and change to our political system to make it far more transparent and accountable."
}

This belief that the political system is "broken" is in large part a reaction to revelations of the abuse of expenses of 2009. In the third reading debate on the Parliamentary Constituencies and Voting Bill, Nick Clegg declared:

\begin{abstract}
"I am sure I do not need to remind Members of the damage that was done by the expenses scandal, which lifted the lid on a culture of secrecy, arrogance and remoteness, right at the heart of the democracy. The coalition Government are determined to turn the page on that political culture and give people a political system they can trust" (House of Commons Debates, 2 November 2010, col 802).
\end{abstract}

In July 2010, the government published two major Bills providing for constitutional change with regard to House of Commons elections - a Parliamentary Voting System and Constituencies Bill, and a Fixed-Term Parliaments Bill. In addition it committed itself to a wholly or mainly directly elected House of Lords, a Localism Bill, decentralizing power to local authorities and local communities, and a European Union Bill requiring a referendum before future treaty amendments or significant transfers of power to the European Union can be ratified. This Bill would also contain a declaratory clause reiterating that Parliament was sovereign.

\section{PARLIAMENTARY VOTING AND CONSTITUENCIES BILL}

The Parliamentary Voting System and Constituencies Bill provided for three reforms. They were:

(i) A reduction in the number of MPs from 650 to a fixed number of 600

(ii) A new set of rules to be used by the Boundary Commissions to ensure greater equalization of constituency boundaries, and more frequent boundary reviews.

(iii) A referendum on the alternative vote method of election to the House of Commons, which was held on the first Thursday of May in 2011, and which resulted in a defeat for the proposal by a majority of around two to one on a turnout of around 42 per cent.

In 1950, the House of Commons had contained 625 MPs. By 2010, this number had grown to 650, even though the devolved bodies had taken over many of the constituency responsibilities of Scottish, Welsh and Northern Irish MPs. Nevertheless, population growth and the lowering of the voting age to 18 mean that the average MP represents a far larger constituency today than in 1950. In 1950 , the total electorate was $34,412,255$. By 2005, it 
had grown to 45,610,369, an increase of around 30 per cent. In 1945, the average MP represented a constituency of around 66,000; today the figure is around 96,000; following the reduction it will be around 105,000, a 60 per cent increase since 1945. This increase has caused an increase in the workload of MPs.

Moreover, constituents are far more demanding of their MPs than they were 60 years ago, a period of deference when many MPs visited their constituency somewhat infrequently. In the 1930s, one MP's “conscientious approach to local interests in Lanark puzzled Collins [Sir Godfrey Collins, Secretary of State for Scotland, 1932-36].” Asked how often he visited his constituency in Greenock, Collins replied: "Five times in 30 years" (D R Thorpe, Alec Douglas-Home, Sinclair Stevenson 1996, p 54). Clement Attlee refused to conduct a constituency surgery on the grounds that it dealt with local matters, whereas his task was to concern himself with matters of high policy at Westminster. In the 1950s, Hugh Gaitskell, Shadow Chancellor and then Leader of the Opposition, received just 20 letters a month from constituents. One of his colleagues, Charles Pannell, the MP for West Leeds, never held a constituency surgery at all (Philip M. Williams, Hugh Gaitskell, Jonathan Cape, 1979, p 380; Brian Brivati, Hugh Gaitskell, Richard Cohen Books, 1996, p 158). It is unlikely that there are any MPs who do not hold constituency surgeries today. They have become, in effect, ombudsmen for their constituents, intermediaries between their constituents and an increasingly complex administration. A reduction in the number of MPs could, therefore, lead to some alienation on the part of constituents lost in the thickets of modern administration.

If there are fewer MPs, but the number of ministers remains the same, then legislative scrutiny will be weaker. Even without the proposed reduction in the number of MPs, there would be a strong case for reducing the statutory maximum number of ministers entitled to sit and vote in the House of Commons. In 1900, when Britain ruled an empire covering a quarter of the world, there were just 60 ministers. By 1950, this had increased to 81, and by January 2010, 119. While the Cabinet increased only from 19 in 1900 to 23 in 2010, the number of ministers below Cabinet rank increased from 41 in 1900 to 96 in 2010. Over a quarter of Conservative and Liberal Democrat MPs were ministers. A further 32 MPs were Parliamentary Private Secretaries. The average cost of each minister, including secretaries, offices etc. is apparently around $£ 500,000$, as well as "tying down a lot of civil service resources" (House of Commons Public Administration Select Committee, Too Many Ministers?, 9th Report, 2009-10, HC 457, para 16). The former Cabinet Secretary, Lord Turnbull, told the Commons Public Administration Committee in January, 2010 that the number of ministers could be reduced by 50 per cent.

In a speech to the Institute for Government in January 2010, Nick Clegg proposed that, in addition to a reduction in the number of MPs to 500, the number of ministers in both houses should be cut to 73 . Nevertheless, on 25 October 2010, the coalition government resisted an amendment to reduce the statutory maximum number of MPs in the Commons under the House of Commons Disqualification Act and the Ministerial and Other Salaries Act, both of 1975, from 95 to 87, directly reflecting the percentage reduction in the number of MPs. But David Heath, Deputy Leader of the House of Commons, declared that "it is likely that at some stage in the future we will reduce the number of Ministers" (House of Commons Debates, 25 October 2010, col 129).

\section{THE EQUALISING OF CONSTITUENCIES}

The second proposal embodied in the Parliamentary Voting System and Constituencies Act provides for new rules to be used by the Boundary Commissions. The current rules, originally established in 1944 in the House of Commons (Redistribution of Seats) Act, and subsequently amended and consolidated in various later Acts of Parliament, provide for Boundary Commissions for England, Scotland, Wales and Northern Ireland. The Commissioners are required to define an electoral quota for their territory by dividing the total number of electors by the number of constituencies. Largely for historical reasons, there is a different electoral quota for each of the four territories in the United Kingdom. In 2010, the average constituency electorate in each of the four territories was:

\section{England 71,882 \\ Scotland 65,498 \\ Northern Ireland 63,101 \\ Wales 56,545}

Once the Commissioners have defined a quota, they are then required to make recommendations for constituency boundaries according to a complex set of rules, which, so it has been argued, are "ambiguous and unclear, and so invite inconsistency in treatment”(D.J. Rossiter, R.J. Johnston and C.J. Pattie, The Boundary Commissions: Redrawing the UK's Map of Parliamentary Constituencies, Manchester University Press, 1999, p 400). Equality of constituencies is just one of these rules, rule 5, which declares that "the electorate of any constituency shall be as near the electoral quota as is practicable", but this rule is not given primacy. There are in consequence large variations in constituency size. Once the Commissioners have published their conclusions, there is provision for a public inquiry if a local authority or more than 100 electors object to a particular recommendation. The process is time-consuming, and the last boundary review in England took seven years to complete. In consequence, even after a boundary review, constituency sizes fail to register recent population changes. In 2010, the electoral register was based on figures from the year 2000. Because 
population movement is in general from Labour-voting inner cities to Conservative-voting rural areas and the more marginal suburbs, deficiencies in the boundary review process generally work to the disadvantage of the Conservatives (Michael Balinski, Ron Johnston, Iain McLean and Peyton Young, Drawing a New Constituency Map for the United Kingdom: The Parliamentary Voting System and Constituencies Bill, 2010, British Academy Policy Centre, 2010, p.29).

The Parliamentary Voting System and Constituencies Bill seeks to secure equal constituencies, an ideal first put forward by the Chartists nearly 200 years ago. It provides that, instead of quotas for the four territories of the United Kingdom, there will be a single quota for the whole country, and primacy will be given to the rule that every constituency must have an electorate within just 5 per cent of the quota (with the exception of the Orkney and Shetland Islands, Comhairle nan Eilean Siar (the Western Isles), and also the Isle of Wight). Public inquiries are to be abolished, but the period of public consultation is to be extended from 4 to 12 weeks. The first review under the rules will be completed by October 2013, which is 18 months before the end of the 2010 Parliament and the proposed date of the next general election. But the review will be based on the December 2010 electoral roll, and therefore, if the next election is held in 2015, the boundaries will still be over four years out of date. Subsequent reviews are to be completed at five year intervals, so that each review will occur 18 months before the date of the general election if Parliament runs its full term.

The reform has been criticized on the ground that, while the old rules provided for community feeling, the new ones give primacy to numerical equality. An opposition Labour spokesman, Chris Bryant, argued that:

"A system that delivers mathematical perfection may be aseptically clean, and please the tidy utilitarian and the centralist, but it will in countless cases leaves voters on the wrong side of a river, a mountain, a county or ward boundary, or cultural divide, and, thereby fail the fundamental tests that we should be setting" (House of Commons Debates, 1 November 2010, col 657).

A Liberal Democrat, MP, Andrew George, representing a Cornish constituency, predicted that:

"When people wake up to the full reality of the way the boundaries are to be divided, they will understand that it will result in the effective pasteurization of Parliamentary constituencies. They will be homogenized and we will see the denigration of place, the denigration of identity and the promotion of placelessness and bland uniformity" (House of Commons Debates, 1 November 2010, col 680).

"Constituencies", James Callaghan, declared, as Home Secretary in 1969, "are not merely areas bounded by a line on a map; they are living communities with a unity, a history and a personality of their own" (House of Commons Debates, 19 June 1969, col. 742).
It may be that voters would prefer to be under-represented rather than abandon strong community ties in the interests of "the tyranny of arithmetic."

Regular and more frequent boundary reviews will only achieve the aim of equalizing constituencies if the electoral register is efficient. If the register does not include all those eligible and if the inefficiencies are not random but skewed towards one particular type of constituency, then that type of constituency will find itself under-represented. The Electoral Commission has calculated that the register is only around 90 per cent efficient, and that around 3 million people who ought to be on it, and indeed are legally required to ensure that they are on it, are in fact excluded. These absent names comprise primarily the young, students and members of ethnic minorities, who are more likely to live in inner city and Labour-voting constituencies than in the countryside.

On the Commission's figures, the number of missing voters exceeded the majority of the sitting MP in 2005 in 160 seats. The Commission found that the lowest rates of completeness and accuracy of the register were in two densely populated areas with highly mobile populations, Lambeth, and the city of Glasgow, chosen as case studies. The report suggested that there were around 100,000 unregistered voters in these two areas. Glasgow would be almost certainly entitled to six constituencies rather than the five which it would be given on the numbers in the current register. Until the register becomes more efficient, therefore, there will be fewer inner city constituencies than there ought to be (Electoral Commission, The Completeness and Accuracy of Electoral Registers in Great Britain, March 2010).

The government has announced that it will produce proposals for individual registration in an attempt to deal with this problem.

In the 2010 general election, it took more votes to elect a Conservative MP than a Labour MP. The electorate in seats won by Labour is on average smaller than the electorate in seats won by the Conservatives. The figures were:

\section{Labour 69,145}

\section{Conservative 73,031}

There are five reasons for this disparity.

The first reason is that Wales is over-represented and Scotland slightly over-represented as compared with England at Westminster. The electoral quotas for Wales and Scotland have been determined independently from that in England. Wales has been over-represented in relation to England relative to her share of the United Kingdom electorate since 1945, and this probably yields around four extra seats to Labour. Scotland was similarly overrepresented until it was given legislative devolution in the 1998 Scotland Act, when her representation was intended 
to be reduced to the English level. Even so, Scotland remains slightly over-represented. Northern Ireland was deliberately under-represented at Westminster during the first period of devolution from 1920 to 1972, but this precedent was not followed in the case of Scotland.

The second reason for the disparity is that the average size of constituencies in England represented by Conservative MPs is larger than the average size of those represented by Labour MPs, precisely because the boundary reviews have failed to keep up with population movements. Between 2001 and 2005, for example, the electorate grew by around 1,000 votes in the average Conservative constituency but fell by around 500 in the average Labour constituency. In 2010, the average size of constituencies won by the Conservatives had 3,886 more names on the electoral register than the average Labour constituency.

In 2010 this difference in constituency electorates was worth 18 seats to Labour out of the total of the 54 extra seats that Labour would have won if its vote had been equal to that of the Conservatives. This, however, means that variations in electorate size cannot be used to explain the whole of the total bias of the electoral system against the Conservatives. Such variations, it has been said, "have contributed no more than one-third of the total bias" (Balinski et al, Drawing a New Constituency Map, pp 30-1). What are the other reasons for it?

There are three other factors, which cannot be remedied by any redistribution of constituencies, however speedy and efficient. The first factor is that turnout is higher in Conservative than in Labour constituencies -68.4 per cent as compared to 61.1 per cent in 2010. On average, 4,161 more voters turn out in a Conservative constituency than in a Labour constituency. If one adds this to the 3,886 more names on the electoral register in Conservative constituencies, differential turnout means that the average Conservative constituency contains 8,047 more voters than the average Labour constituency. Differential turnout probably accounted for 32 of the 54 extra seats that Labour would have won if its vote had been equal to that of the Conservatives.

A second factor which has disadvantaged the Conservatives in recent elections, though not in 2010, is that the Labour vote has been more concentrated than the Conservative vote and therefore better distributed from the point of view of winning seats. The Liberal Democrat vote is the least concentrated of that of the three major parties. In elections before 2010, Labour won more seats than the Conservatives by narrow majorities and wasted fewer votes building up large majorities in safe seats or coming a good second. Therefore it won a larger number of seats than the Conservatives for any given share of the vote. In 2010, for purely contingent reasons, there seems to have been no geographical effect of this sort between the major parties.
The final factor has been the differential effect of tactical voting. In 2010, Labour voters proved more willing to vote Liberal Democrat in Conservative/Liberal Democrat marginals, than Conservative voters were to vote Liberal Democrat in Labour/Liberal Democrat marginals. This differential effect probably cost the Conservatives around four seats.

The bias against the Conservatives, therefore, does not arise solely, or even primarily, from constituency malapportionment, but from three other factors differential turnout, differential concentration of the vote and the differential effects of tactical voting. These effects cannot be corrected by any boundary review, however efficient.

Under the first past the post electoral system, the number of seats which a party wins will depend not only upon how many votes it receives, but also upon how that vote is distributed geographically. A party whose vote is more concentrated will in general win more seats for a given share of the vote than a party whose vote is more evenly spread.

Electoral bias, therefore, cannot be wholly eliminated by reform of the rules under which the Boundary Commissions operate. Supporters of this reform exaggerate its likely benefits.

\section{FIXED-TERM PARLIAMENTS}

The coalition's Programme for Government declared:

"We will establish five-year fixed-term Parliaments. We will put a binding motion before the House of Commons stating that the next general election will be held on the first Thursday of May 2015. Following this motion, we will legislate to make provision for fixed-term Parliaments of five years."

A precondition for the formation of the coalition was control over the dissolution of Parliament. Otherwise the Prime Minister would have been able to secure a snap dissolution at a favourable moment for his party, breaking up the coalition, at the expense of his coalition partners.

Amongst western European Parliamentary systems, however, all of which apart from France use a system of proportional representation to elect their lower house, Norway is the only country that makes provision for fixedterm Parliaments, the Parliamentary term being four years. This, however, causes considerable difficulty when a government is defeated on a confidence vote in the middle of a Parliamentary term as has happened on three occasions in Norway in the last 30 years. Switzerland also has a fixed-term Parliament, but it is not strictly a Parliamentary system since the executive is drawn from all of the main parties in the legislature, rather than solely from the majority party or parties, and is not responsible to it. 
But the Fixed-Term Parliaments Act is misnamed. It does not provide for fixed term Parliaments on the Norwegian model, although it does make dissolution more difficult and no longer at the discretion of the government of the day.

The Bill provides two methods by which an early dissolution can be secured. The first is when two-thirds of MPs vote for it. In the current Parliament, this means that both Conservative and Labour MPs would have to support a dissolution.

The second method of securing an early dissolution occurs if, after a vote of no-confidence in the government, no alternative government can be formed within 14 days. This provision is similar to that regulating the Scottish Parliament in the Scotland Act, 1998, with two exceptions. The first is that, in Scotland, the Parliament is given 28 days to nominate a First Minister. The second exception is that, in Scotland, if there is an early dissolution, the election that follows is termed an "extraordinary general election", and the "ordinary general election" held after four years still takes place. Thus, if the Scottish Parliament, elected in 2007, had been dissolved in 2009, there would still have been another election in 2011. (The only exception to this provision occurs if the "extraordinary general election" is held within six months of the date of the "ordinary general election." In these circumstances, the ordinary general election is not held: Scotland Act, 1998 and see, in particular, ss 3(1)(a) and (b) and s 46). The provision that any general election held after a vote for dissolution or vote of no-confidence is an "extraordinary general election" which does not affect the normal cycle, has the effect of lessening the potential advantage of an early dissolution for an incumbent government.

But the coalition did not adopt the Scottish provision. This means that a mid-term dissolution initiates a new five year term. If the mid-term election is held earlier in the year than May, the next general election is held four years later; if later than May, five years later. Thus, a mid-term dissolution held in February 2012 would mean that the next general election would be in May 2016; but a midterm dissolution held in October 2012 would mean that the next general election would be in May 2017.

An early dissolution, so it is argued, represents an illegitimate attempt by a Prime Minister to gain an advantage from the temporary popularity of his government. But there are respectable reasons for an early dissolution. The first is when a new Prime Minister seeks a personal mandate, as with Sir Anthony Eden in 1955. Some felt that Gordon Brown should have sought such a mandate in 2007. Indeed, in April 2010, shortly before the general election, David Cameron proposed that a new Prime Minister should go to the country within six months of being appointed (Independent, 24 April, 2010).

A second reason for an early dissolution might be to seek a mandate for a new policy, as with Baldwin who, in 1923, dissolved a Parliament that was just one year old, in an unsuccessful attempt to secure a mandate for a protective tariff; or with Edward Heath in February 1974, who, again unsuccessfully, sought a mandate to deal with the miners' strike and changed economic conditions resulting from the quadrupling of oil prices after the 1973 Yom Kippur war.

A third reason for an early dissolution might be that the existing Parliament is unviable, as with the 1950-51 Parliament, the 1964-6 Parliament or the FebruaryOctober 1974 Parliament, when governments lacked a working majority.

A fourth reason might be if there were a change of coalition partners in the middle of a Parliament when it could be argued that the electorate should be given the chance to pronounce on this change of government.

These four motives for early dissolution are by no means unworthy.

The Fixed-Term Parliaments Bill was introduced as a reaction to the expenses scandal. But the main problem that appears to have been raised by the expenses scandal was the need to secure greater control over MPs who, so it was alleged, had become insensitive to the reactions of their constituents. If the Fixed-Term Parliaments Bill has any effect, however, it would be to insulate MPs from popular pressures by ensuring that dissolution became more difficult and general elections less frequent.

The debate about the Fixed-term Parliaments Act indicates a conflict between two fundamental principles, the principle of Parliamentary government and the principle of democratic government. The former principle provides that Parliament shall choose the government, which is accountable to it, the second that the people should choose the government, and that government should be accountable to them. Normally, of course, under single-party majority government, the norm since 1945, though not before 1939, the two principles coincide. But if, as is possible, we are moving into an era of multi-party politics, then the principles will come to diverge.

If we are entering a world of hung Parliaments, it by no means necessarily follows that dissolutions should be made more difficult. Indeed, it can be argued that they should become more frequent since changes of government in mid-Parliament are more likely to occur in a multi-party system than under a two-party system where coalitions are unnecessary. While a democracy cannot survive on an endless diet of dissolutions, making dissolution too difficult could lead to endless Parliamentary manoeuvring of the sort which so discredited the Third and Fourth Republics in France. Dissolution, then, is not necessarily a threat to good Parliamentary government, but can instead be one of its most important safeguards by ensuring that governments are accountable not only to Parliament but also to the electorate. In Third Republic France, in 1902, Prime Minister, Waldeck-Rousseau declared: "the ability to 
dissolve — is not a menace to universal suffrage, but its safeguard. It is the essential counterbalance to excessive Parliamentarism, and for this reason it affirms the democratic character of our institutions" (quoted in B S Markesinis, The Theory and Practice of Dissolution of Parliament, Cambridge University Press, 1972, p 234).

\section{CONCLUSION}

The coalition exemplifies the principle of Parliamentary government rather than the principle of democratic government, in that neither the formation of the government nor the coalition agreement could be endorsed by the people; while the constitutional reforms proposed by the coalition might well serve to insulate Parliament still further from the people.

Perhaps, therefore, the constitutional reforms of the coalition need to be counter-balanced by reforms designed to open up the political system not further to insulate it.
There is a profound conflict between the politics of Parliamentarism and the politics of a democratic age. So the constitutional changes proposed by the coalition will not end the era of constitutional reform. That era will come to an end only when our political system has come to be congruent with the public philosophy of the age, when the forms of the constitution come to be congruent with the predominant forces animating society.

\section{Vernon Bogdanor CBE}

Research Professor, Institute of Contemporary History, King's College, London; Emeritus Gresham Professor of Law; Fellow of the British Academy

- This article is based on a lecture entitled "The coalition and the constitution" given at the IALS on May 23, 2011.

\section{Articles for Amicus Curiae}

Amicus Curiae welcomes contributions, which should be accompanied by the name and contact details of the author. The journal publishes articles on a wide variety of issues, ranging from short pieces of 700-1,200 words and longer articles of 4,000 words of so (the upper limit can be extended where appropriate). Articles should be written in an informal style and without footnotes.

Anyone interested in submitting a piece should email Julian Harris (julian.harris@sas.ac.uk). 